EESTI NSV TEADUSTE AKADEEMIA TOIMETISED, 27. KOIDE GEOLOOGIA, 1978, NR. 3

ИЗВЕСТИЯ АКАДЕМИИ НАУК ЭСТОНСКОИ ССР. ТОМ 27 ГЕОЛОГИЯ. 1978, № 3

\title{
ТРИЛОБИТЫ ВИДОВОЙ ГРУППЫ ENCRINURUS PUNCTATUS В ВЕНЛОКЕ ПРИБАЛТИКИ
}

Видовая группа Encrinurus punctatus выделена Ф. Ридом (Reed, 1928) и детально описана P. Триппом (Tripp, 1962). Согласно этим авторам, виды данной группы характеризуются слабо выраженными базальными лопастями и предглабельной бороздой, крупными бугорками на глабели и ложном предглабельном поле, хорошо развитыми щечными шипами, а также многочисленными рахиальными кольцами и гладким осевым поясом на пигидии. Группа типична в основном для венлока.

Нижне- и среднелландоверийские энкринуриды Прибалтики характеризуются отсутствием щечных и хвостовых шипов, большим количеством бугорков на глабели и ложном предглабельном поле и чаще всего умеренным количеством рахиальных колец на пигидии. Они близки к видам E. shelvensis и E. mullochensis Англии (Whittard, 1938) и относятся, видимо, к самостоятельной группе видов, называемой здесь группой $E$. rotundus.

Из верхнего лландовери Прибалтики известно шесть видов энкринурид, два из которых - E. rumbaensis и E. palmrei - относятся к группе $E$. rotundus. Два - E. schmidti и $E$. triangulus - занимают промежуточное место между видами групп $E$. rotundus и $E$. punctatus. E. schmidti имеет, как и $E$. punctatus, четко выраженные щечные и хвостовые шипы, но заметно отличается от него наличием многочисленных бугорков на глабели. E. triangulus более близок к E. punctatus, отличается от него лишь небольшим количеством рахиальных колец на пигидии, заостренными щечными углами и слабой туберкуляцией на щеках и рахисе пигидия. E. triangulus и E. schmidti можно условно отнести к членам группы E. punctatus, выделять же группу E. schmidti (Мянниль, 1968) теперь нецелесообразно. Остальные известные верхнелландоверийские виды - E. pilistverensis и $E$. quinquecostatus - разнятся от других энкринурид наличием пяти пар плевральных ребер на пигидии и, вероятно, принадлежат к особому роду. Однако мы располагаем пока только пигидиями этих видов (Rosenstein, 1941; Мянниль, 1958).

Все известные венлокские энкринуриды Прибалтики относятся к группе E. punctatus. Их типовой вид происходит из обнажений окрестностей Яани, а описанные ниже новые виды E. ruhnuensis и E. balticus из сравнительно глубоководных отложений.

В настоящей статье используется та же терминология, что и при описании лландоверийских энкринурид (Мянниль, 1968, 1977б). Экземпляры, предварительно покрытые хлористым аммонием, фотографировались с помощью кругообразной лампы. Описанный материал хранится в Институте геологии АН ЭССР в Таллине. 


\section{Encrinurus punctatus (Wahlenberg)}

Табл. I, фиг. 1-7; табл. II, фиг. 1-6

1821. Entomostracites punctatus - Wahlenberg, c. 32, табл. 2, фиг. 1.

1857. Encrinurus punctatus Brünn. - Nieszkowski, с. 604, табл. III, фиг. 6, 7.

1881. Encrinurus punctatus Wahlb. - Schmidt, c. 225, табл. XIV, фиг. $11-13$; табл. XV, фиг. 18.

1937. Encrinurus punctatus (Wahl.) - Öpik, c. 118, табл. XXV, фиг. 4.

1941. Encrinurus punctatus (Wahl.) - Rosenstein, с. 53, табл. 1, фиг. $1-11$; табл. 2, фиг. $1-3,5$; табл. 3, фиг. $1-10$.

1956. Encrinurus punctatus (Wahl.) - Tripp and Whittard, с. 259, табл. 3, фиг. $1,2$.

1962. Encrinurus punctatus (Wahl.) - Tripp, с. 461, табл. 65, фиг. 9-14; табл. 66, фиг. 2, 3; табл. 67, фиг. 5-8; табл. 68, фиг. 7, 8, 10.

Л е к тоти п. Пигидий, № 1200, хранится в музее Палеонтологического института университета Уппсала (Wahlenberg, 1821, табл. 2, фиг. 1; Tripp, Whittard, 1956, с. 259, табл. 3, фиг. 1, 2). Готланд.

М а те р и а л. 5 почти полных спинных щитов, 18 кранидиев, 10 гипостом, 5 подвижных щек и около 200 пигидиев.

Ди а гноз. Глабель несет около 30 бугорков, пальпебральное поле 2 , реже 3 бугорка. На ложном предглабельном поле 8 бугорков. На подвижной щеке 4 дугообразно расположенных бугорка. Псевдоглабельное поле подвижных щек покрыто 18-20 крупными бугорками. Глаз широкий, пальпебральная лопасть бугорчатая. Срединные борозды гипостомы вогнуты. Пигидий удлиненно-треугольный, конец заострен в виде короткого шипа. На рахисе в среднем $28(25-32)$ колец и 7 бугорков. Имеется 8 пар плевральных ребер, на их проксимальных частях расположено по одному бугорку.

З а меч а ни я. Вид детально описан Э. Розенштейн (Rosenstein, 1941) и Р. Триппом (Tripp, 1962). Э. Шранком поставлен вопрос об объеме вида (Schrank, 1972). Кстати, уже Э. Розенштейн отмечала, что готландские формы, названные E. punctatus, относятся, видимо, к разным таксонам. По-видимому, и Р. Триппом присвоены видам E. punctatus и E. macrourus слишком большие диапазоны изменчивости и стратиграфические амплитуды. По нашему мнению, хвостовые щиты энкринурид имеют хорошие, довольно устойчивые диагностические признаки, и поэтому исключено, чтобы у экземпляров одного и того же вида хвостовой шип либо был, либо не был. Лектотип E. punctatus достаточно хорошо позволяет сравнить прибалтийские формы группы $E$. punctatus с таковыми о-ва Готланд. Форма из окрестностей Яани сходна с лектотипом как по морфологическим признакам (количеству рахиальных колец, очертанию пигидия и др.), так и по возрасту (по определению Е. Хеде, лектотип происходит из венлокских отложений, вероятно, из слоев Хёгклинт - Tripp, 1962). Происходящие из обнажений Яани и Хёгклинт кранидии также сходны. Наша форма отличается от готландской в основном лишь отсутствием глабельного бугорка $\mathrm{iii}-0$ и более крупными paхиальными бугорками на пигидии.

Наиболее молодые венлокские формы E. punctatus происходят из слоев Слите (Tripp, 1962, табл. 65, фиг. 10; табл. 68, фиг. 10). Аналогичные формы найдены в Прибалтике в разрезе скв. Каугатума в интервале $127-158$ м. Те и другие отличаются от вышеназванных форм бо́льшим количеством бугорков на ложном предглабельном поле (обычно 10), более мелкими рахиальными бугорками на пигидии, плоским лопа. 
тообразным концом и плоскими плевральными ребрами на пигидии, ввиду чего боковые края расчленены довольно слабо (табл. II, фиг. 5,6 ).

Для сравнения $E$. punctatus c $E$. macrourus представлены фотографии топотипических экземпляров последнего из коллекции Ф. Шмидта (табл. II, фиг. 7-9).

Р а спространени е. Венлок. Обнажения яаниского горизонта на о-ве Сааремаа; скв. Пярну, $58,7-111,4$ м; скв. Пярну («Ливония»), $90,5-105,8$ м; скв. Каугатума, $127-184,6$ м; скв. Икла, 266-280,5 м; скв. Охесааре, 216-217,4 м. О-в Готланд, слои Хёгклинт и Слите.

\section{Encrinurus balticus sp. n.}

Табл. III, фиг. $1-16$

1927. Encrinurus punctatus Wahl. sp. - Kummerow, табл. I, фиг. 19.

1972. Encrinurus (E.) cf. punctatus macrourus Schmidt, 1859 - Schrank, c. 43 , табл. XIII, фиг. 1,2 .

1977a. Encrinurus balticus nom. nud. - Мянниль, с. 151.

Голо т и п. Кранидий, $\operatorname{Tr} 1998$, скв. Колка, 428,8 м. Венлок.

М а тер и а л. 12 кранидиев, 8 подвижных щек, 5 гипостом, 14 пигидиев. Д и агноз. На глабели $27-38$ бугорков, типичная пара базальных бугорков I - 1. Ложное предглабельное поле несет 8, пальпебральное поле 3 , подвижная щека 7-10 бессистемно расположенных бугорков. Пигидий широкий, хвостовой шип длинный и тонкий. На рахисе от 17 до 21 кольца.

О писание. Глабель слабо выпуклая, отношение длины к ширине $1,1-1,2$. Передняя часть глабели в $1,6-1,7$ раза шире задней. Боковые борозды и предглабельная борозда нечеткие, последняя слабо выражена только по бокам. Относительно ясные валикообразные базальные лопасти кончаются в осевой части глабели бугорками I - 1. Спинные борозды умеренно глубокие и широкие, сильно расходящиеся. Имеются длинные щечные шипы $(3,2-4,5$ мм). Длинные и узкие пальпебральные лопасти несколько удалены от спинных борозд. Подвижная щека имеет относительно широкую равномерную краевую кайму и умеренно широкую неглубокую борозду.

Скульптура выражена четко по всему головному щиту. На глабели в среднем $33(27-38)$ относительно одинаковых по величине бугорков (диаметром до 1 мм), более крупных на боковых лопастях. У голотипа расположение бугорков по системе Р. Триппа (Tripp, 1962) следующее: I -1 ; II $-1,2$; III $-1,2,3$; iv -0 ; IV $-1,2,3$; V -0 ; V $-1,2,3$; $\mathrm{VI}-1,2$. Наиболее типичная пара базальных бугорков I -1 . Второй ряд состоит из 2-3 бугорков, нередко встречается срединный бугорок iii - 0. Ложное предглабельное поле несет восемь бугорков, по величине аналогичных бугоркам на боковых лопастях. Обнаружен лишь один экземпляр (табл. III, фиг. 11) с девятым бугорком в середине. Приглабельная часть неподвижной щеки покрыта также крупными бугорками, к бокам они уменьшаются и располагаются менее густо. На пальпебральном поле чаще три, иногда четыре бугорка. На подвижной щеке 6-7 нерегулярно расположенных больших и несколько мелких второстепенных бугорков. Псевдоглабельное поле покрыто $18-20$ разными по величине бугорками, по боковой кайме проходит ряд низких бугорков. На верхушке бугорка обычно находится пора. Поверхность бугорков, передней и боковой кайм и гипостомы зернистая.

Гипостома с умеренно выпуклым срединным телом. Передний конец тела закруглен и слегка нависает над передним краем гипостомы. Сре- 
динные борозды прямые, расходящиеся назад. Передняя и боковые каймы узкие, задняя кайма в виде языка с закругленным концом занимает около $1 / 5$ длины всей гипостомы. Макулы в виде эллиптических бугорков расположены около заднебокового края срединного тела.

Торакс не найден.

Пигидий широкий, треугольного очертания, с длинным хвостовым шипом. Отношение ширины пигидия к его длине (без учета шипа) около 1,7. Рахис относительно узкий, занимает четверть ширины пигидия, ограничен прямыми спинными бороздами. На рахисе от 17 до 21 кольца, рахиальные борозды в осевой части выражены слабо. На плевральном поле семь ребер, отделенных друг от друга широкими межплевральными бороздами. Хвостовой шип узкий и длинный, составляет около $2 / 5$ длины пигидия. Скульптура четкая. Осевые бугорки, в количестве 5-6, располагаются чаще всего на $2,6,10,14$ и 17-м кольцах. На проксимальных частях плевральных ребер просматриваются четкие бугорки по одному на каждом, кроме четвертого ребра, на котором обычно два бугорка.

И з м ен ч и в ость. Варьируют количество бугорков на глабели (2738), расположение бугорков на пигидии и длина щечного шипа.

С р а внен и е. Описанный вид отличается от остальных прибалтийских видов группы $E$. punctatus наличием базальных бугорков I -1 , нерегулярным расположением бугорков на подвижной щеке, широким, четко туберкулированным пигидием, длинным хвостовым шипом и небольшим количеством рахиальных колец на пигидии.

От E. tuberculatus наш вид разнится наличием на глабели бугорков I - 1, иным расположением бугорков на щечном и пальпебральном полях и прямыми срединными бороздами гипостомы. Он похож на $E$. macrourus (из нижнего лудлова о-ва Готланд) длинным хвостовым шипом, широкими межплевральными бороздами и относительно четкими базальными лопастями на глабели. Отличается от E. macrourus наличием бугорков I - 1, отсутствием срединного девятого бугорка на ложном предглабельном поле, тонким хвостовым шипом (у E. macrourus он имеет широкое подножье, образованное последней вытянутой парой плевральных ребер) и более широким пигидием.

Р а с п р ост р а нен ие. Венлок. Скв. Колка, 421,6-459,7 м; скв. Охеcaаpe, $271,4-292,3 \mu$.

\section{Encrinurus ruhnuensis sp. $\mathrm{n}$.}

Табл. II, фиг. 10-13; табл. IV, фиг. 1-2

1972. Encrinurus (E.) cf. punctatus 2 - Schrank, c. 38, табл. XI, рис. $1,2,7$.

1977a. Encrinurus ruhnuensis nom. nud. - Мянниль, с. 151.

Голоти п. Спинной щит с гипостомой, Tr 2760, скв. Рухну, 392,5 м. Венлок.

Ма тери ал. 3 спинных щита, 3 кранидия, 2 подвижные щеки и 5 пигидиев.

Д и а г о з. Ложное предглабельное поле несет восемь, глабель 27-28 бугорков, характерный бугорок $\mathrm{iii-0.} \mathrm{Глаза} \mathrm{узкие} \mathrm{и} \mathrm{длинные.} \mathrm{На} \mathrm{под-}$ вижной щеке пять дугообразно расположенных бугорков. Щечные шипы короткие, хвостовой шип по длине умеренный. Рахис пигидия имеет от 23 до 25 колец.

О пи с ан ие. Очертание глабели и спинные борозды похожи на таковые́ у вышеописанных видов. Широкие и сильно выпуклые щеки поднимаются до уровня глабели. На вершине щечного поля есть расположен- 
ный близко к глабели узкий и длинный глаз. Щечные шипы короткие. Рострум внизу сильно расширяется и выступает в виде бугорка.

Скульптура на глабели представлена 27-28 крупными субконическими бугорками, относительно одинаковыми по величине (диаметром 0,7-1 мм). На ложном предглабельном поле восемь бугорков, они немного крупнее бугорков на глабели. У голотипа расположение бугорков следующее: II - 1, 2; iii - 0; III - 1, 2; iv - 1; IV $-1,2,3$; v - 0; V - I, 2,$3 ; \mathrm{VI}-1,2$. Неподвижная щека в приглабельной части покрыта разными по величине бугорками, постепенно уменьшающимися к бокам. На пальпебральном поле $2-3$ бугорка, на подвижной щеке пять дугообразно расположенных бугорков. Глаз окружен бугорчатым венчиком, вытянутым к боку (у экземпляров из скв. Рухну). На боковой части щеки небольшие ямки. Псевдоглабельное поле неподвижных щек покрыто 22-28 бугорками, по величине более мелкими, чем на глабели. На боковой кайме проксимально расположен ряд больших, плоских, уменьшающихся кзади бугорков и дистально - небольшие бугорки.

Торакс состоит из 11 сегментов. Ширина рахиса занимает около $1 / 3$ ширины торакса. Сочленовые борозды четкие. Кольца рахиса и плевральные сегменты в продольном сечении слегка закруглены. На десятом кольце небольшой срединный бугорок.

Пигидий треугольный с умеренным по длине шипом. Длина пигидия в 1,1 раза больше его ширины (без хвостового шипа). Рахис ограничен слегка выгнутыми спинными бороздами и занимает около $1 / 3$ ширины пигидия. Осевой пояс в передней своей части имеет нечеткие осевые борозды, после третьего кольца гладкий. На рахисе выделяется от 23 до 25 колец, на плевральном поле восемь пар ребер, из них последняя, находясь в зачаточном состоянии, не доходит до края пигидия. Скульптура пигидия выражена 5-7 осевыми бугорками. У голотипа они расположены на 2, $5,9,12,16,20$ и 23-м кольцах, но нередко начинаются от первого кольца. На плевральных ребрах имеется по одному невысокому бугорку, расположенному так же, как у E. punctatus.

Из менчивость проявляется в основном в различном количестве

\section{Таблица I}

Фиг. 1-7. Encrinurus punctatus (Wahl.). $\mathrm{J}_{1} .1$ - головной щит, $\operatorname{Tr} 1921$, обн. Парамая (Rosenstein, 1941, табл. 1, фиг. 1-4; Tripp, 1962, табл. 65, фиг. 14): 1а - общий вид, $\times 3,16$ - переднебоковой вид, $\times 3,1$ в - пальпебральная лопасть, $\times 5,7 ; 2$ - гипостома, $\operatorname{Tr} 2786, \times 3$, скв. Пярну, $91,8 м ; 3$ - полусвернутый спинной щит, $\operatorname{Tr} 2775, \times 2,6$, обн. Парамая; За - общий вид, Зб - переднебоковой вид, Зв - вид спереди, 3г вид сбоку; 4 - спинной щит с четким срединным бугорком на седьмом кольце рахиса, $\operatorname{Tr} 2774, \times 3$, там же; 5 - гипостома, $\operatorname{Tr} 2777, \times 3$, там же; 6 -гипостома, $\operatorname{Tr} 2788, \times 3$, там же; $6 а$ - вид сверху, $6 б-$ вид сбоку; 7 - пигидий, $\operatorname{Tr} 2772, \times 2,5$, там же.

Таблица II

Фиг, 1-6. Encrinurus punctatus (Wahl.). W. 1 - пигидий, $\operatorname{Tr} 2781, \times 3$, обн. Парамая; 2 - пигидий с исключительно большим количеством бугорков на рахисе, $\operatorname{Tr} 2780, \times 2,3$, там же; 3 - пигидий, $\operatorname{Tr} 2782$, Х3, там же; За - вид сверху, 3б - вид сбоку; $4-$ пнгидий, $\operatorname{Tr} 2785, \times 3$, скв. Пярну (жЛивония»), 105,8 м; 5 - пигидий, $\operatorname{Tr} 2784, \times 2,4$, скв. Каугатума, 134,85 м; 6 - пигидий, $\operatorname{Tr} 2783$, Х3, скв. Каугатума, 158,8 м.

Фиг. 7-9. Encrinurus macrourus Schmidt. Ld. Петесвик, о-в Готланд (из коллекции Ф. Шмидта). 7 - лектотип, задняя часть спинного щита, $\operatorname{Tr} 1905, \times 3$ (Tripp, 1962, табл. 67, фиг. 4 a, b); 8 - кранидий, $\operatorname{Tr} 1909, \times 3 ; 9-$ пигидий, $\operatorname{Tr} 1907, \times 3$.

Фиг, 10-13. Encrinurus ruhnuensis sp. n. W. $10-$ кранидий, $\operatorname{Tr} 2000, \times 3$, скв. Охеcaаре, $290,45 \mu ; 11$ - спинной щит, Tr $2759, \times 3$, скв. Рухну, 392,9 м; 12 - пигидий и кранидий, $\operatorname{Tr} 1997, \times 3$, скв. Охесаaре, $292,4 м$; 13 - пигидий с коротким шипом, Tr $2758, \times 4$, скв. Рухну, 413,9 м; 13а - вид сверху; 136 - вид сбоку. 


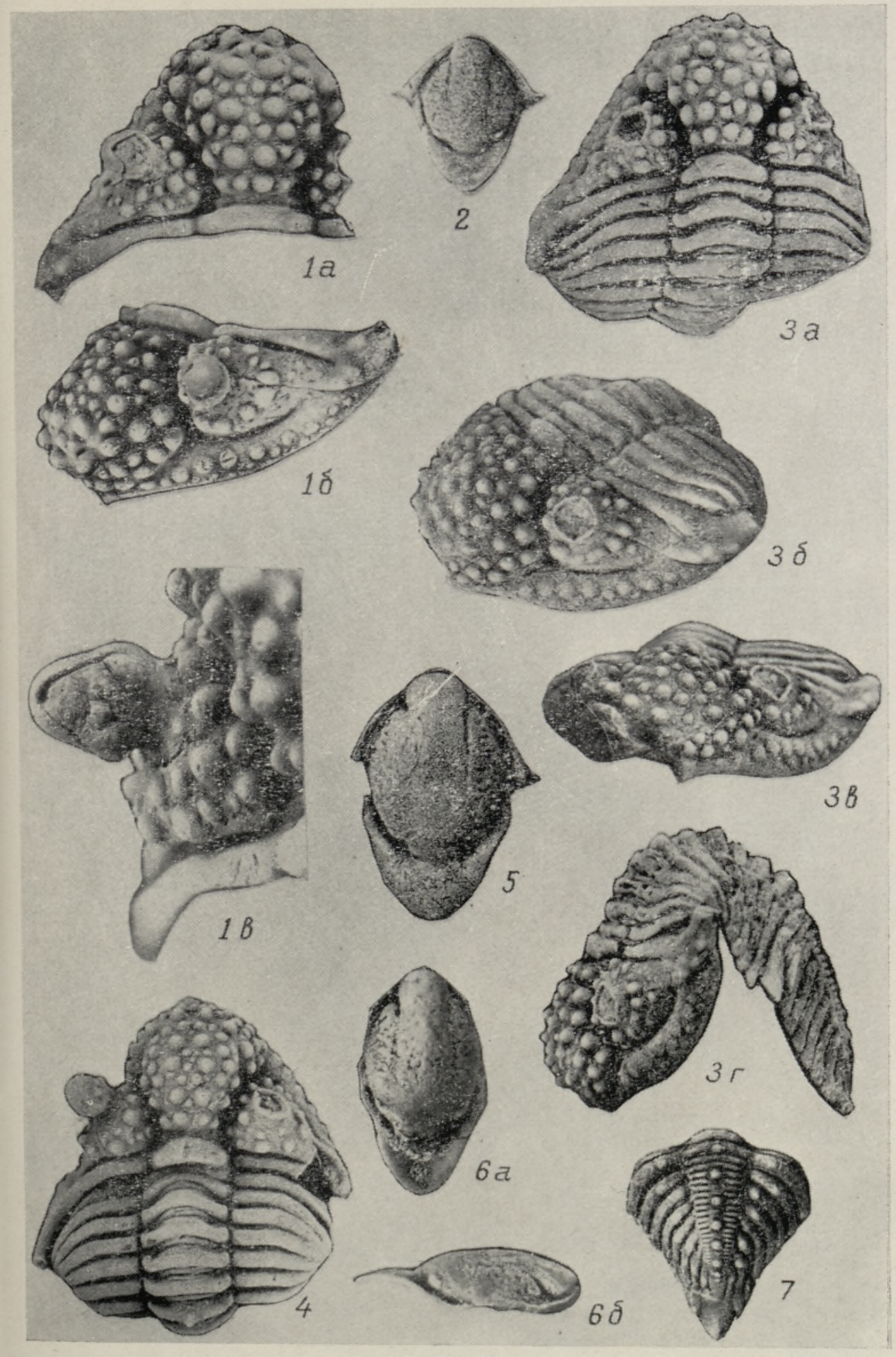




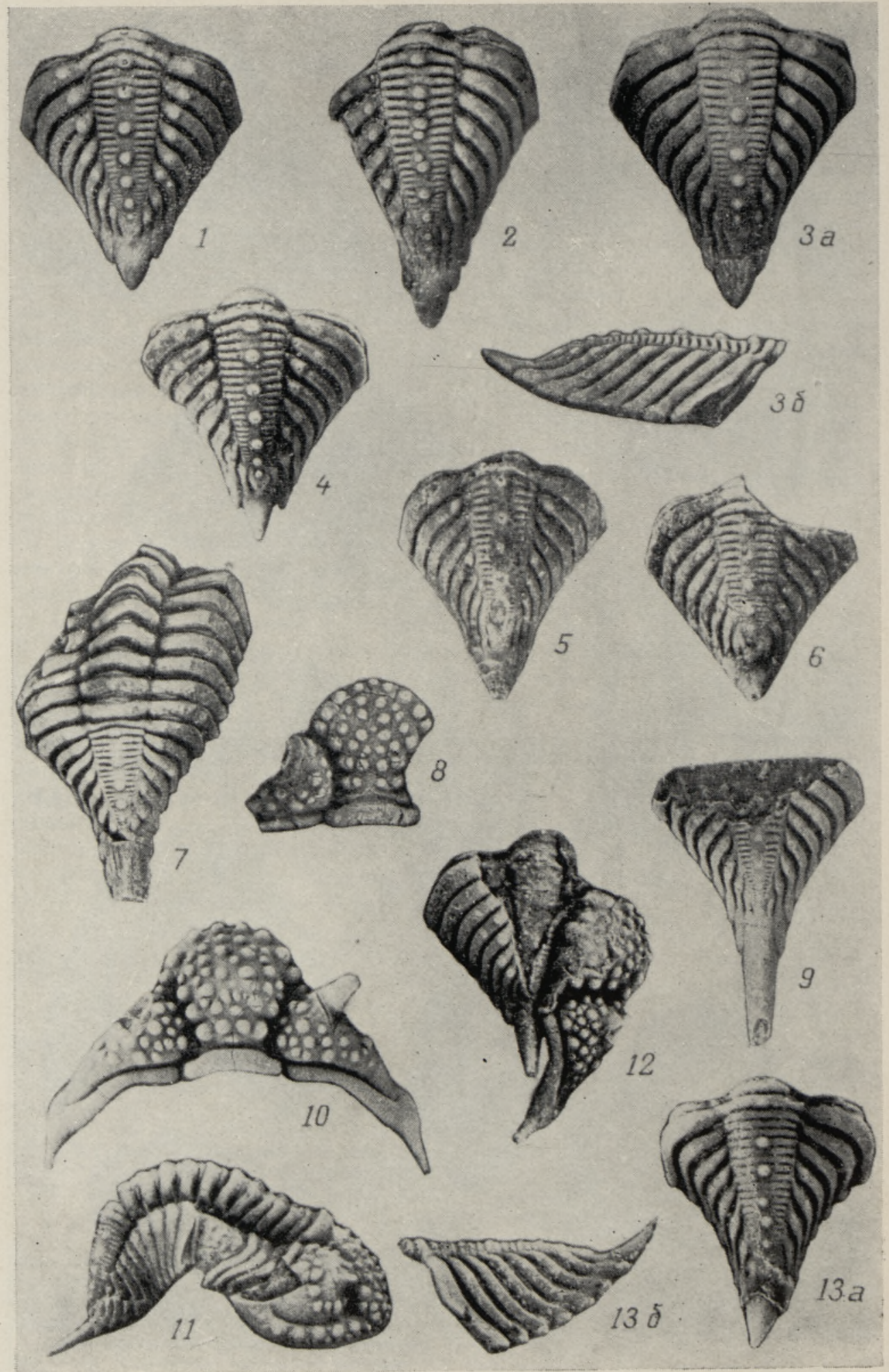




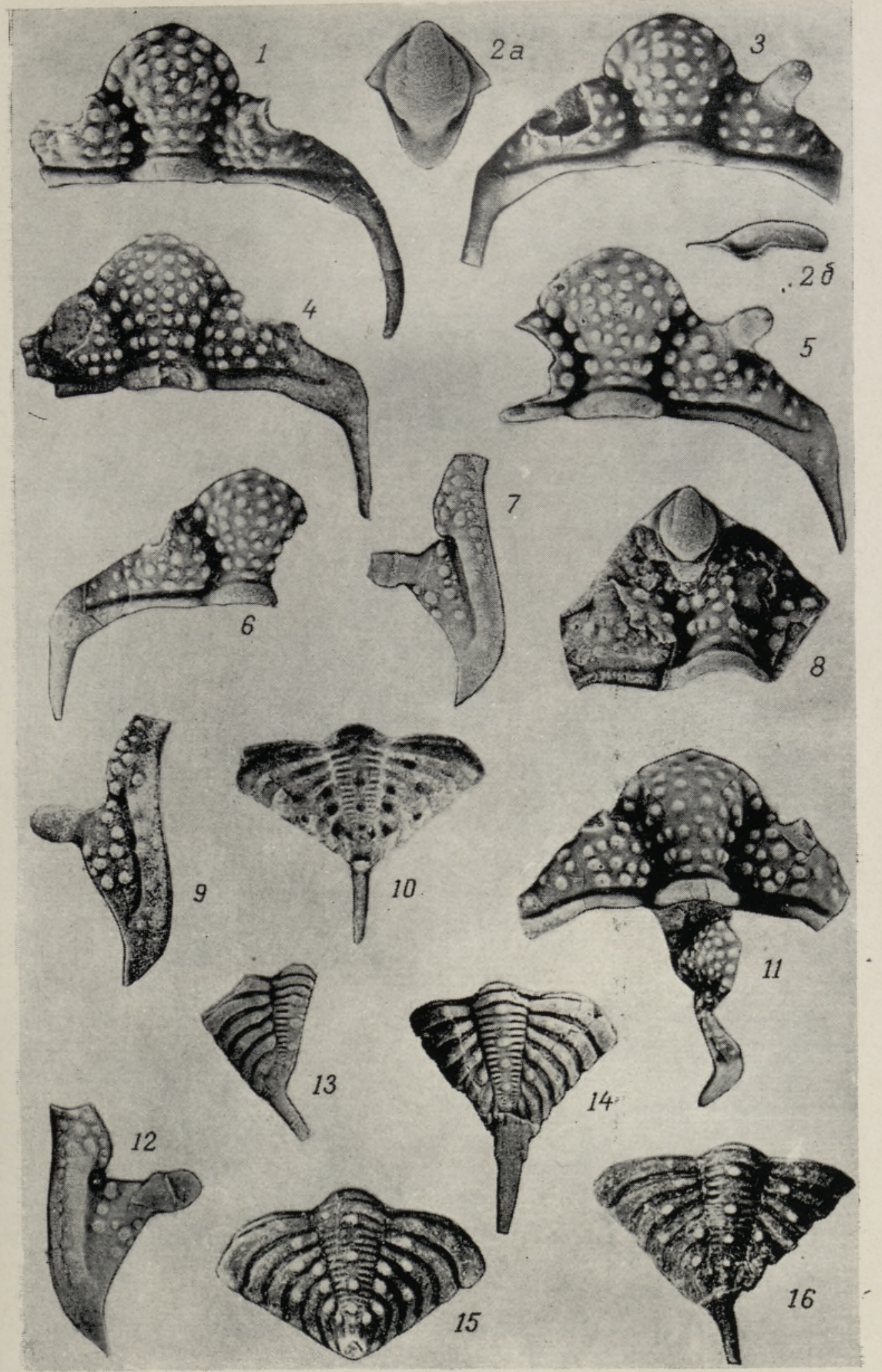




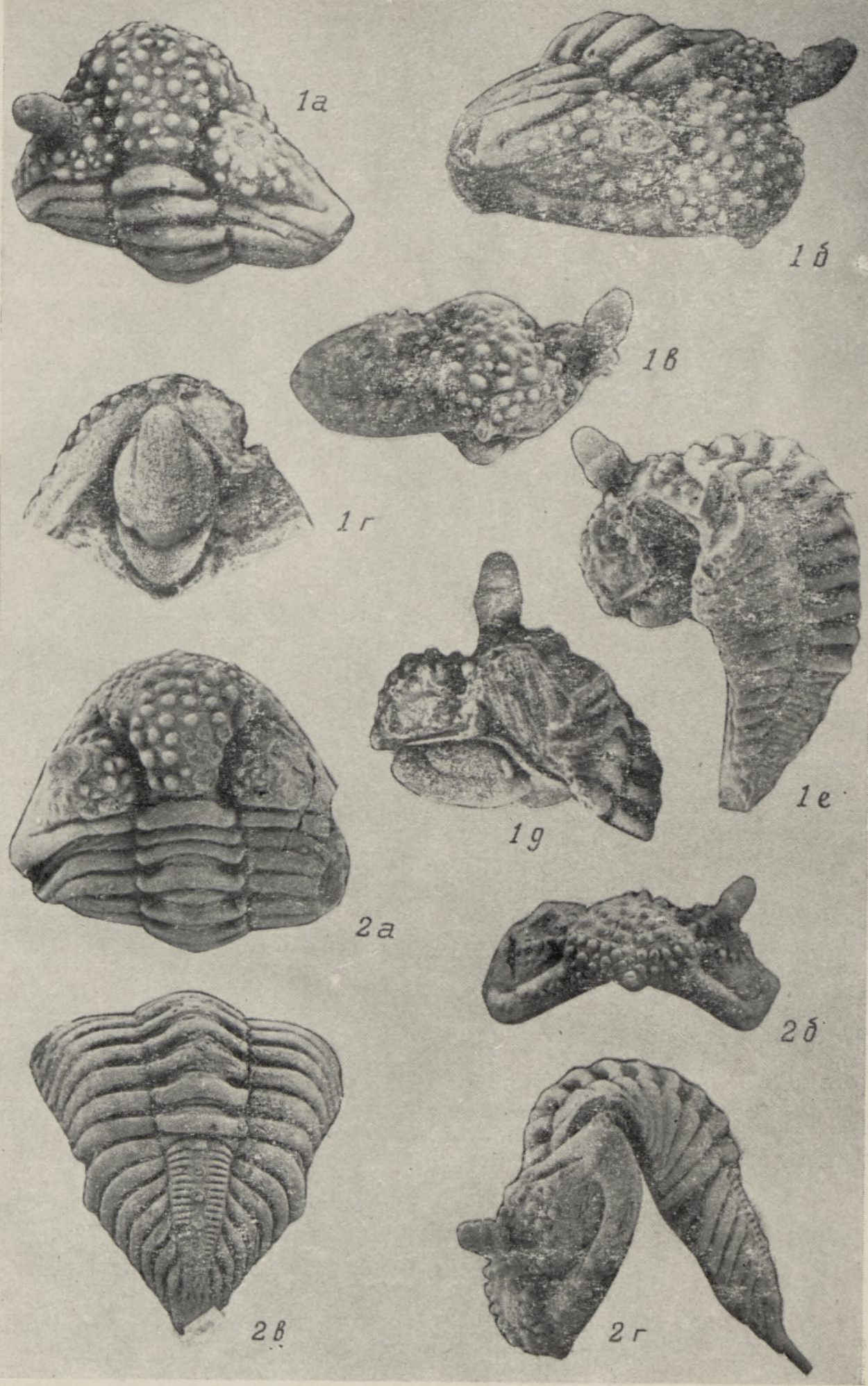


бугорков на глабели и пальпебральном поле, в расположении бугорков на пигидии и в длине хвостового шипа. Экземпляры из скв. Охесааре характеризуются невытянутым бугорчатым венчиком на подвижной щеке, бо́льшим количеством бугорков на псевдоглабельном поле и у не-

Размеры изученных экземпляров, мм

\begin{tabular}{|c|c|c|c|c|c|c|c|c|c|}
\hline & \multicolumn{2}{|c|}{ E. punctatus } & \multicolumn{5}{|c|}{ E. balticus } & \multicolumn{2}{|c|}{ E. ruhnuensis } \\
\hline & $\begin{array}{c}\mathrm{Tr} \\
2775\end{array}$ & $\begin{array}{c}\mathrm{Tr} \\
2781\end{array}$ & $\begin{array}{c}\mathrm{Tr} \\
1998\end{array}$ & $\begin{array}{c}\mathrm{Tr} \\
1989 \mathrm{a}\end{array}$ & $\begin{array}{c}\mathrm{Tr} \\
1988\end{array}$ & $\begin{array}{c}\mathrm{Tr} \\
2757 \mathrm{~b}\end{array}$ & $\begin{array}{c}\mathrm{Tr} \\
1989 \mathrm{c}\end{array}$ & $\begin{array}{c}\mathrm{Tr} \\
2760\end{array}$ & $\begin{array}{c}\mathrm{Tr} \\
2441\end{array}$ \\
\hline Длина & & & & & & & & & \\
\hline $\begin{array}{l}\text { кранидия } \\
\text { Ширина }\end{array}$ & 10,0 & - & 6,0 & 6,5 & 7,9 & - & - & 8,2 & 7,7 \\
\hline $\begin{array}{l}\text { кранидия } \\
\text { Длина }\end{array}$ & 23,0 & - & 18,5 & 18,0 & - & - & - & 18,0 & 18,0 \\
\hline $\begin{array}{l}\text { глабели } \\
\text { Ширина }\end{array}$ & 7,5 & - & 4,5 & 5,0 & 6,0 & - & - & 6,5 & 5,8 \\
\hline $\begin{array}{l}\text { глабели } \\
\text { спереди } \\
\text { Ширина }\end{array}$ & 6,5 & - & 3,9 & 4,1 & 5,0 & - & - & 5,3 & 5,4 \\
\hline $\begin{array}{l}\text { глабели } \\
\text { сзади } \\
\text { Длина }\end{array}$ & 3,7 & - & 2,5 & 2,7 & 3,2 & - & - & 3,0 & 3,5 \\
\hline $\begin{array}{l}\text { щечного } \\
\text { шипа } \\
\text { Длина } \\
\text { пигидия }\end{array}$ & - & - & 4,5 & 3,2 & - & - & - & - & - \\
\hline $\begin{array}{l}\text { с шипом } \\
\text { Длина } \\
\text { пигидия }\end{array}$ & - & 13,0 & - & - & - & 10,0 & - & - & 12,0 \\
\hline & 11,6 & 11,5 & - & - & - & 6,1 & 8,0 & - & 9,5 \\
\hline $\begin{array}{l}\text { пигидия } \\
\text { Длина }\end{array}$ & 11,5 & 11,5 & - & - & - & 11,4 & 12,5 & - & 10,9 \\
\hline $\begin{array}{l}\text { рахиса } \\
\text { Ширина }\end{array}$ & 11,0 & 10,3 & - & - & - & 5,5 & 6,5 & - & 8,0 \\
\hline рахиса & 4,6 & 4,2 & - & - & - & 2,8 & 3,4 & - & 3,7 \\
\hline
\end{tabular}

Таблица III

Фиг, 1-16. Encrinurus balticus sp. n. W. 1 - голотип, кранидий, $\operatorname{Tr} 1998, \times 4$, скв. Колка, 428,8 $м ; 2$ - гипостома, $\operatorname{Tr} 1955$, Х4, скв. Колка, 425,6 м; 2а - общий вид, 26 - вид сбоку; 3 - кранидий, $\operatorname{Tr} 1994$, Х4, скв. Колка, 421,6 м; 4 - кранидий, $\operatorname{Tr} 1989 \mathrm{~b}, \times 3$, скв. Колка, 438,9 м; 5 - кранидий, $\operatorname{Tr} 1989 \mathrm{a}, \times 4$, там же; 6 - кранидий, $\operatorname{Tr} 1990, \times 3$, скв. Колка, 456,5 м; 7 - подвижная щека, $\operatorname{Tr} 1992, \times 3$, скв. Колка, $440,5 м ; 8-$ часть кранидия и гипостома, $\operatorname{Tr} 1996, \times 4$, скв. Колка, 432,5 ; 9 - подвижная щека, $\operatorname{Tr} 2757 \mathrm{a}, \times 3$, скв. Колка, 434,5 м; 10 - слепок пигидия, $\operatorname{Tr} 2757 \mathrm{~b}, \times 3$, там же; 11 - два кранидия (у большого экземпляра в середине ложного предглабельного поля есть как исключение девятый бугорок), $\operatorname{Tr} 1988, \times 3$, скв. Колка, 457,1 $м$; 12 - подвижная щека, $\operatorname{Tr} 1991, \times 3$, скв. Колка, 459,7 м; 13 - пигидий, $\operatorname{Tr} 1987, \times 3$, скв. Колка, 429,2 м; 14 - пигидий с широким подножьем шипа, $\operatorname{Tr} 1993$, Х2, скв. Колка, $454,2 м ; 15$ - пигидий с отламанным шипом, $\operatorname{Tr} 1989$ c, $\times 3$, скв. Колка, 438,9 м; $16-$ пигидий, $\operatorname{Tr} 2773 \mathrm{~b}, \times 3$, скв. Колка, 436,6 м.

\section{Таблица IV}

Фиг. 1-2. Encrinurus ruhnuensis sp. n. W. 1 - голотип, полусвернутый спинной щит с гипостомой, Tr $2760, \times 3$, скв. Рухну, 392,5 м: 1а - общий вид сверху, 16 - переднебоковой вид, 1в - вид спереди, 1г - вид на гипостому снизу, 1д - вид на гипостому сбоку, 1е - общий вид сбоку; 2 - полусвернутый спинной щит, $\operatorname{Tr} 2441, \times 3$, скв. Охеcaаре, 295,0 м: 2а - общий вид на переднюю часть щита, $26-$ вид спереди, 2в - вид на заднюю часть щита, 2 г - вид сбоку. 
которых особей присутствием третьего бугорка на пальпебральном поле. Наиболее древние находки вида из скв. Рухну $(413,4-413,9$ м; табл. II, фиг. $13, a, \sigma)$ имеют короткие хвостовые шипы, весьма похожие на шипы E. punctatus.

C р а в нен и е. Описанный вид отличается от E. balticus наличием бугорков іiі-0 и отсутствием базальных бугорков I-1 на глабели, венкообразным расположением бугорков на подвижной щеке, более короткими щечными и хвостовыми шипами, относительно узким пигидием, узкими межплевральными бороздами и бо́льшим количеством рахиальных колец на пигидии.

От E. punctatus отличается узкими глазами, более мелкими бугорками на псевдоглабельном поле, прямыми срединными бороздами гипостомы и более длинным хвостовым шипом. По наличию бугорка iіi - 0 наш вид сходен с готландской разновидностью E. punctatus. По строению пигидия (количеству рахиальных колец, длине хвостового шипа) и некоторым признакам кранидия E. ruhnuensis можно считать переходным видом от $E$. punctatus к $E$. balticus.

От E. tuberculatus наш вид отличается отсутствием бугорков III $-2 *$ * ме́ньшим количеством бугорков на глабели, нечетким бугорком на десятом кольце торакса и прямыми срединными бороздами гипостомы. Р а спростр анени е. Венлок. Скв. Рухну, 388,4-413,9 м; скв. Охеcaape, $290,45-295,0$ M.

\section{Л И Т Е Р А Т Р Р А}

М янни ль Р. M. 1958. Трилобиты семейств Cheiruridae и Encrinuridae из Эстонии. Тр. Ин-та геол. АН ЭССР, III, $165-212$.

М янн и ль Р. 1968. Encrinurus schmidti sp. n. (Trilobita) из лландовери Эстонии. Изв. АН ЭССР, Хим. Геол., 17, 273-278.

Мянниль Р. П. 1977а. Распространение трилобитов в силуре Прибалтики. В сб.: Кальо Д. Л. (ред.). Фации и фауна силура Прибалтикн. Таллин, с. $149-158$.

М янниль Р. 19776 . Новые энкринуриды (Trilobita) лландовери Прибалтики. Изв: АН ЭССР, Хим. Геол., 26, 46-56.

K u mmerow, E. 1927. Beitrag zur Kenntnis der Fauna und der Herkunft der Diluvialgeschiebe. Jb. preuss. geol. Landesanst., 48, $1-59$.

$\mathrm{Nieszkowski,} \mathrm{J.} \mathrm{1857.} \mathrm{Versuch} \mathrm{einer} \mathrm{Monographie} \mathrm{der} \mathrm{in} \mathrm{den} \mathrm{silurischen} \mathrm{Schichten}$ der Ostseeprovinzen vorkommenden Trilobiten. Arch. Naturk, Liv-, Ehst- u. Kurl., Ser. 1, Bd. 1, 112 S.

Reed, F. R. C. 1928. Notes on the Family Encrinuridae. Geol. Mag., 65, 51-77.

Rosenstein, E. 1941. Die Encrinurus-Arten des estländischen Silurs. Publ. Geol. Inst. Univ. Tartu, Nr. 62, 49-77.

$\mathrm{Schmidt}$, Fr. 1881. Revision der ostbaltischen silurischen Trilobiten. I. Mém. Acad, Sci. St.-Petersb., sér. 7, 30, Nr. 1, $238 \mathrm{~S}$.

Schrank, E. 1972. Proetacea, Encrinuridae und Phacopina (Trilobita) aus silurischen Geschieben. Beiheft Zeitschr. Geologie, 76, $117 \mathrm{~S}$.

Tripp, R. P. 1962. The Silurian trilobite Encrinurus punctatus (Wahlenberg) and allied species. Palaeont., 5, 460-477.

Tripp, R. P., Whittard, W. F. 1956. Proposed use of the plenary powers (a) to designate type species in harmony with accustomed usage for the genera "Encrinurus" Emmrich, 1844, and "Odontochile" Hawle and Corda, 1847 and (b) to validate the specific name "punctatus" Wahlenberg, 1821, as published in the combination "Entomostracites punctatus" (Class Trilobita). Bull. Zool. Nomencl., 12, 259-263.

W a hlenberg, G. 1821. Petrificata telluris Svecanae. Nova Acta Soc. Sci. Upsal., (5), 8, $1-116$.

Whittard, W. F. 1938. The Upper Valentian Trilobite Fauna of Shropshire. Annals and Mag. Natur. History, ser. II, 1, 85-140.

Op i k, A. 1937. Trilobiten aus Estland. Publ. Geol. Inst. Univ. Tartu, 52, 163 S.

\footnotetext{
Ннститут геологии

Академии наук Эстонской ССР
}

Поступила в редакцию 15/III 1977 
Reet MANNIL

\section{ENCRINURUS PUNCTATUS'E RUHMA TRILOBIIDID BALTIKUMI UENLOKIS}

Baltikumi uenloki enkrinuriidid kuuluvad $E$. punctatus'e rühma ja on esindatud liikidega E. punctatus, E. balticus sp. n. ja E. ruhnuensis sp. n.

\section{Reet MANNIL}

\section{WENLOCKIAN TRILOBITES OF THE ENCRINURUS PUNCTATUS SPECIES-GROUP OF THE EAST BALTIC}

The Encrinurus punctatus species-group is represented in the East Baltic Wenlockian rocks by $E$. punctatus, E. balticus sp. n. and E. ruhnuensis sp. n.

Encrinurus balticus sp. n.

Pl. III, Figs $1-16$

Glabella weakly convex, with $27-38$ tubercles. Typical are basal tubercles I-1. Eight tubercles on false preglabellar field, 7-10 irregulary placed tubercles on free cheek. Pygidium wide, with long and slender posterior spine. Pygidium composed of $17-21$ rings and seven pairs of pleurae. On each pleura usually one tubercle, on the fourth pleura two.

Borings of Kolka $(421.6-459.7 \mathrm{~m})$ and Ohesaare $(271.4-292.5 \mathrm{~m})$. Wenlock.

Encrinurus ruhnuensis sp. n.

Pl. II, Figs 10-13; Pl. IV, Figs $1-2$

Moderately convex glabella with $27-28$ tubercles, among them typical tubercle iii-0. Eight tubercles on false preglabellar field. Palpebral lobes slender. On free cheek five tubercles, placed in a row. Genal spine short. Pygidium with posterior spine of moderate lenght, composed of 23-25 rings and eight pairs of pleurae.

Borings of Ruhnu $(388.4-413.9 \mathrm{~m})$ and Ohesaare $(290.45-295.0 \mathrm{~m})$. Wenlock. 